\title{
Food Source for Hydropsychid Larvae during an Algae Bloom in Nan River, Nan Province, Thailand (Trichoptera: Hydropsychidae)
}

\author{
PORNPIMON BUNTHA ${ }^{1,2}$, SIRIPEN TRAICHAIYAPORN ${ }^{1,3} \&$ DECHA THAPANYA ${ }^{1,4, *}$ \\ ${ }^{1}$ Department of Biology, Faculty of Science, Chiang Mai University, Chiang Mai 50200, Thailand \\ 2 ”buntha.p.bt@gmail.com; (1) https://orcid.org/0000-0003-0014-4437 \\ 3 |"trsiripen@gmail.com; (1) https://orcid.org/0000-0002-0882-9505 \\ 4 !" thapanya2@hotmail.com; (1) https://orcid.org/0000-0002-5996-6323 \\ ${ }^{*}$ Corresponding author: " thapanya2@hotmail.com
}

\begin{abstract}
During November-March, blooms of Kai algae genera are commonly seen on rocks and cobblestones in the Nan River, providing habitat for hydropsychid larvae. This study attempted to determine a dietary relationship between the caddisflies and Kai algae by comparing gut contents of hydropsychid larvae between areas with and without Kai algae (Kai-blooming and Control sites). Fourteen specimens of Hydropsyche and Potamyia larvae were collected in the Kai-blooming and Control sites, respectively. Food items in the foreguts were classified as Kai algae (KA), other filamentous algae (OFA), diatoms (DT) and other items (OI). Although the main food type of larvae in both sites was Kai algae, the proportion of KA in larval foreguts from Kai-blooming sites was significantly higher than in those from Control sites $(p<0.05)$. In addition, larvae in the Kai-blooming area had a significantly lower proportion of OI than in the Control area $(p<0.05)$. Therefore, hydropsychid larvae tended to consume more Kai algae than diatoms and other filamentous algae during blooming periods. They tended to consume more Kai algae than would be expected by chance alone, even in the area with a small amount of Kai algae.
\end{abstract}

Key words: Kai algae, caddisfly, Cladophora, gut content, Hydropsychidae

\section{Introduction}

Green algae are primary producers in aquatic ecosystems, serving as a food source for aquatic animals as well as helping increase dissolved oxygen concentration that supports their respiration processes. Algae in family Cladophoraceae are distribute in both tropical and temperate zones (tropical zone: Thailand, Laos, Mexico, Brazil, and east coast of South Africa; temperate zone: Austria, Michigan, France, Netherlands, New York, and Switzerland) (Van den Hoek 1963; Whitton 1970; Chaiyasuk \& Waiyaka 2001; Higgins et al. 2008; Lee 2008; Traichaiyaporn 2012). In northern Thailand, Cladophora and Rhizoclonium spp., macro-filamentous green algae, are locally called 'Kai' (Traichaiyaporn 2012) and grow on hard substrates, such as cobblestones and rocks, in running water, such as streams and rivers. Kunpradid (2005) and Pruetiworanan (2008) reported that the dominant species of macro-green algae in the Mekong River, Chiang Rai Province, and the Nan River, Nan Province, were Cladophora and Rhizoclonium spp. Both provinces are in northern Thailand. The algae occur most often in medium to good water quality at water velocity $0.33-0.8 \mathrm{~m} / \mathrm{s}$, depth $0.2-0.8 \mathrm{~m}$, temperature $23.5-28.5^{\circ} \mathrm{C}$, turbidity $10-33 \mathrm{NTU}$, conductivity $226.2-272.8 \mu \mathrm{S} / \mathrm{cm}$, total dissolved solid $225.1-245.5$ $\mathrm{mg} / \mathrm{L}$, pH 7.90-8.21, dissolved oxygen (DO) 7.0-8.8 mg/L, biochemical dissolved oxygen (BOD) 0.4-2.0 $\mathrm{mg} / \mathrm{L}$, nitrate-nitrogen $0.1-0.7 \mathrm{mg} / \mathrm{L}$, ammonia-nitrogen $0.12-0.23 \mathrm{mg} / \mathrm{L}$, and orthophosphate $0.01-0.18 \mathrm{mg} /$ L. The water velocity and turbidity affected the algal production more than DO, BOD, and nutrient concentrations (Kunpradid \& Tagun 2016). The algae are used as a food source by local people in Nan and Chiang Rai provinces during the Kai algae blooming period (November-March or cool season) in the Nan and Mekong Rivers (Chaiyasuk \& Waiyaka 2001; Peerapornpisal et al. 2005; Traichaiyaporn 2012). The Mekong River is the longest river in Southeast Asia. The Nan River originates on Luang Prabang Mountain and is one of four 
main tributaries that flow into the Chao Phraya River, the major river of Thailand. The elevation of the Nan River is 418-540 m above sea level (Wangpimool et al. 2013).

Adult caddisflies in Thailand have been studied since 1987 (Malicky \& Chantaramongkol 1999) and larval studies first mentioned Rhyacophila and Ugandatrichia (Malicky 1987, 1999). Caddisflies were found in a wide range of altitudes, from 400-2,300 m asl. (Malicky \& Chantaramongkol 1993). Studies on caddisflies were accomplished in Doi Inthanon, Phu Hin Rongkla National Park, Doi Suthep-Pui National Park, Mae Jam River, and Ping River in Thailand (Changthong 2005; Silalom 2008; Takeaw 2014; Thongdej 2012).

Caddisfly larvae of family Hydropsychidae are commonly found. High abundances of hydropsychid larvae have been reported in the Tapee River (Laudee \& Prommi 2011), the Mae Tao and Mae Ku watersheds (Prommi \& Thamsenanupap 2015), and Phu Kradueng National Park (Thawaroroit \& Sangpradub 2016). Hydropsychidae also were the most abundant in Dak Pri stream, Vietnam (Hoang \& Bae 2006). Hydropsyche and Potamyia were founded in the streams of Gunung Tebu, Malaysia, at water velocity $0.00-0.30 \mathrm{~m} / \mathrm{s}$, depth 0.20-0.66 m, DO 6.50-7.80 mg/L, BOD 0.63-1.43 mg/L, and ammonia-nitrogen 0.00-0.08 mg/L (Rawi et al. 2013). Hydropsychidae mostly live on hard substrates. Highly stable substratum (e.g., gravel, cobble, rock, and bedrock) is a proper habitat for many aquatic insects, such as larvae of mayflies, stoneflies, and caddisflies. Potamyia larvae construct their net retreats on the tops of rocks or other solid surfaces (Oláh et al. 2006).

Both Kai algae and hydropsychid larvae are abundant on hard substrates in the Nan River during the algal blooming period. Little information is available concerning the coexistence of Kai algae and caddisfly larvae in the Nan River. Therefore, this study explored the relationship of hydropsychid larvae and Kai algae growing in the same habitat in the Nan River. The study will provide information for the biodiversity database of Trichoptera and also help improve understanding of the importance of Kai algae blooms on the feeding habits of hydropsychids and possibly other benthic organisms.

\section{Materials and methods}

Caddisfly larvae in family Hydropsychidae were collected from two study sites (Kai-blooming and Control sites) in the Nan River, Chiang Klang District, Nan Province, Thailand $\left(19.23^{\circ} \mathrm{N}, 100.82^{\circ} \mathrm{E}\right)$ during a Kai bloom in January 2018. The Kai-blooming site had more than $80 \%$ coverage of Kai algae on the stones, whereas the Control site had less than $20 \%$ coverage. The substrate and water depth at the Kai-blooming and Control sites were similar (Figure 1). Water velocity at the Control site was slightly lower than the Kai-blooming site. Characteristics of the Control site showed the normal condition of the Nan River during non-algal blooming periods that nevertheless have some algae on stones on the streambed.
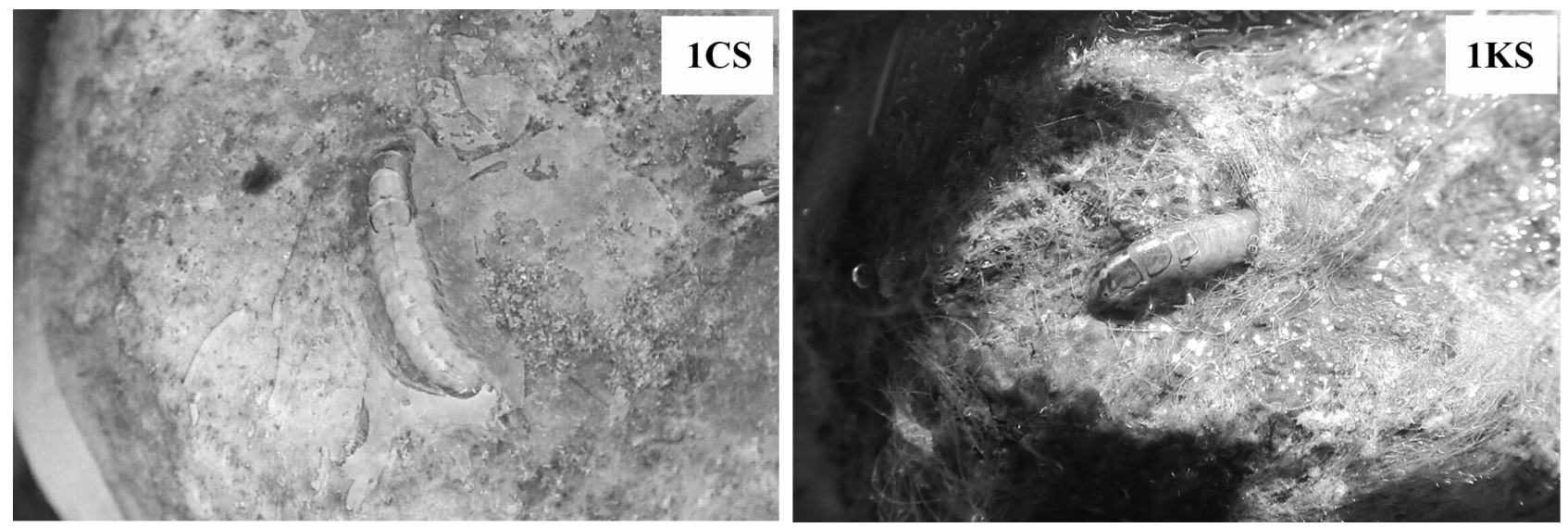

FIGURE 1. Hydropsychidae larvae on cobblestones. 1CS, hydropsychid larva on a cobblestone at a Control site, $1 \mathrm{KS}$, hydropsychid larva on a cobblestone at a Kai-blooming site.

Potamyia and Hydropsyche were dominant groups in the Control and Kai-blooming sites, respectively. Fourteen living specimens with larger than $1 \mathrm{~cm}$ of body size (fourth and fifth instar larvae) from each sampling site were selected by hand picking and then preserved in an ice box at $6-10{ }^{\circ} \mathrm{C}$ for genus-level identi- 
fication in the laboratory according to Dudgeon (1999). Their foreguts were dissected in the Aquatic Insect Research Unit (AIRU), Chiang Mai University. Foreguts were excised from larval bodies by using surgical

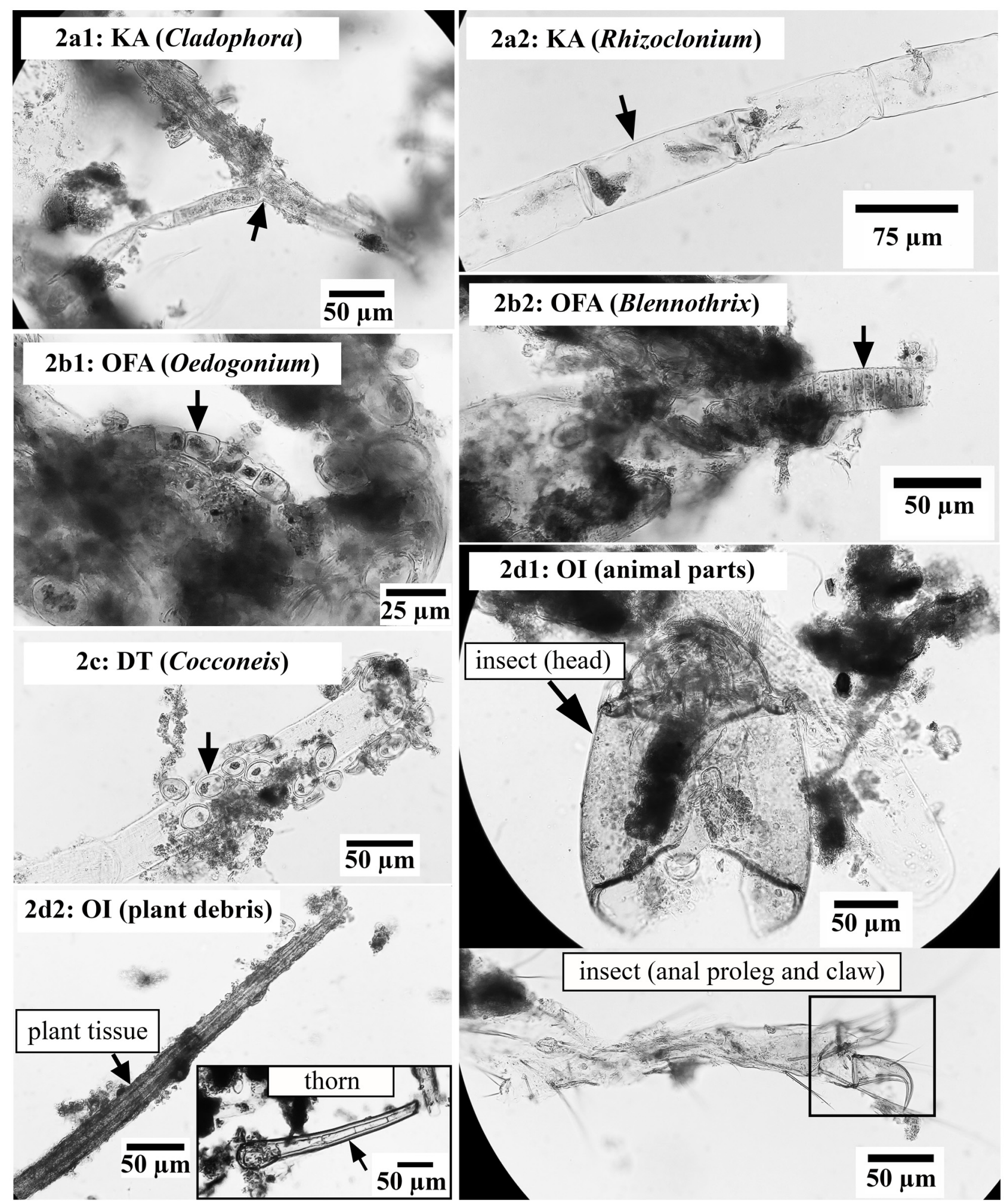

FIGURE 2. Food items in Potamyia larval foreguts from the Control site. 2a, Kai algae (KA): 2a1, Cladophora sp.; 2a2, Rhizoclonium sp. 2b, other filamentous algae (OFA): 2b1, Oedogonium sp.; 2b2, Blennothrix sp. 2c, diatoms (DT): Cocconeis sp. $2 \mathrm{~d}$, other items (OI): $2 \mathrm{~d} 1$, animal parts; $2 \mathrm{~d} 2$, plant debris. 
scissors and forceps under a stereomicroscope according to a method modified from that of Wallace et al. (1987). All food items were removed and put on a glass slide that was then photographed under a compound microscope at 40x magnification for classification. Four types of food items were identified according to Peerapornpisal (2013): Kai algae (KA), other filamentous algae (OFA), diatoms (DT), and other items (OI). The proportion of each food type was calculated by counting items in numbered squares of a grid placed on an enlarged photo (10.3 cm of diameter) according to a haemocytometer method (Moheimani et al. 2013). A paired t-test was run with $\mathrm{R}$ program version 3.3.3 to compare the percentages of four food types between Kaiblooming and Control sites.

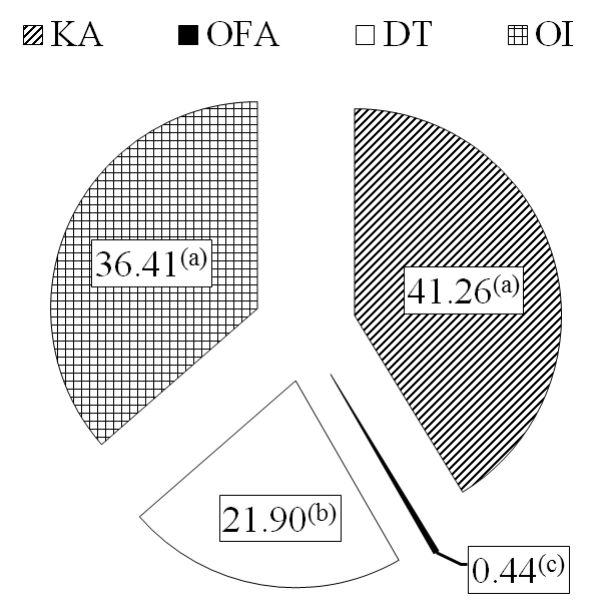

FIGURE 3. Average percentage of four food types in foreguts of 14 Potamyia larvae at the Control site. Different letters (a), (b), and (c) indicate significant difference $(p<0.05) . \mathrm{KA}=$ Kai algae, OFA $=$ other filamentous algae, DT $=$ diatoms, $\mathrm{OI}=$ other items.

Neither the species-level identity nor the number of species captured in our samples of Potamyia and Hydropsyche were observed. Voucher specimens of the Potamyia and Hydropsyche larvae captured and studied in this research are deposited in the Department of Biology, Faculty of Science, Chiang Mai University, Chiang Mai, Thailand.

\section{Results and discussions}

Food types of Potamyia larvae in the Control site

All four food types were found in the foreguts of larvae from the Control site, including Kai algae genera Cladophora (with branching filaments) and Rhizoclonium (with non-branching filaments) (Figures 2a1 and 2a2). Diatoms of genus Cocconeis were attached to most algal filaments (Figures 2a1 and 2c) and were consumed together with the algae. Other filamentous algae (OFA) found were Oedogonium and Blennothrix (Figures 2b1 and 2b2). Diatom (DT) genera Eunotia, Gomphonema, Pinnularia, and Synedra were found in the foreguts. Other items (OI) consisted of animal parts (e.g., head capsules, anal prolegs, and other insect body parts) and plant debris (e.g., plant tissue and thorns) (Figures $2 \mathrm{~d} 1$ and 2d2). The results showed that Potamyia larvae in the Control site were omnivores (consuming both plants and animals).

The proportions of Kai algae (KA) (41.26\%) and other items (OI) (36.41\%) were significantly higher than of DT and OFA $(21.90 \%$ and $0.44 \%$, respectively; $p<0.05)$ (Figure 3$)$. The proportion of DT significantly differed from OFA. Thus, although the Control site had low abundance of Kai algae, Potamyia consumed Kai algae more than diatoms and other filamentous algae. However, although the collected larvae might move from the areas with high abundance of Kai algae, the results show that Kai algae were an important food source for Potamyia larvae. 
Food types of Hydropsyche larvae in Kai-blooming site

Foreguts of larvae at the Kai-blooming site contained all food items, including Kai algae (KA) genera Cladophora and Rhizoclonium (Figures $4 \mathrm{e} 1$ and $4 \mathrm{e} 2$ ). Kai algae filaments in the foreguts were mostly without attached diatoms because most of the algae in the Kai-blooming site were young algae. Broken cells of Kai algae seemed to have been bitten by Hydropsyche larvae, probably to reduce digestion time. Cytoplasm from the broken cells was more easily digested into absorbable nutrients.

Other filamentous algae (OFA) genera Oedogonium and Blennothrix (Figure 4f) and diatom (DT) genera Cocconeis (Figure 4g), Synedra, and Eunotia were found. Pieces of aquatic insect legs, categorized as other food items (OI), indicate that the larvae might hunt living aquatic insects or consume dead parts (Figure 4h). Thus, Hydropsyche larvae in the Kai-blooming site were omnivores, like Potamyia larvae in the Control site, because they consumed several food types including algae, diatoms, and insects.

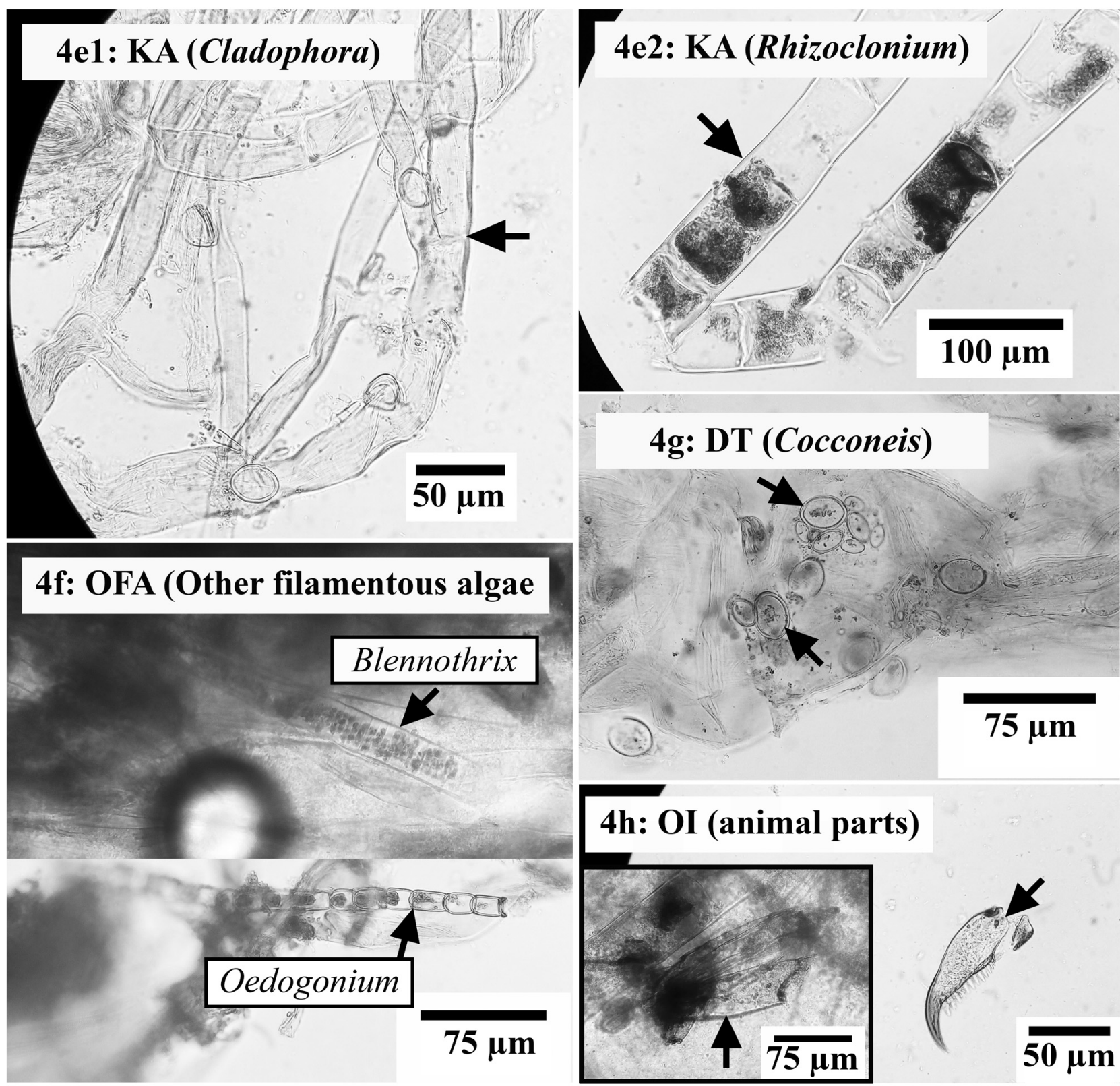

FIGURE 4. Food items in Hydropsyche larval foreguts from the Kai-blooming site. 4e, Kai-algae (KA): 4e1, Cladophora sp.; 4e2, Rhizoclonium sp. 4f, other filamentous algae (OFA, Oedogonium spp. and Blennothrix spp.). 4g, diatoms (DT, Cocconeis spp.). 4h, other items (OI, animal parts). 
Kai algae (KA) were significantly the main food type (77.34\%) consumed by Hydropsyche larvae at the Kai-blooming site, followed by DT, OI, and OFA $(14.85 \%, 4.38 \%$, and $3.44 \%$, respectively; $p<0.05)$ (Figure 5 ), among which the proportions of OI and OFA were not significantly different.

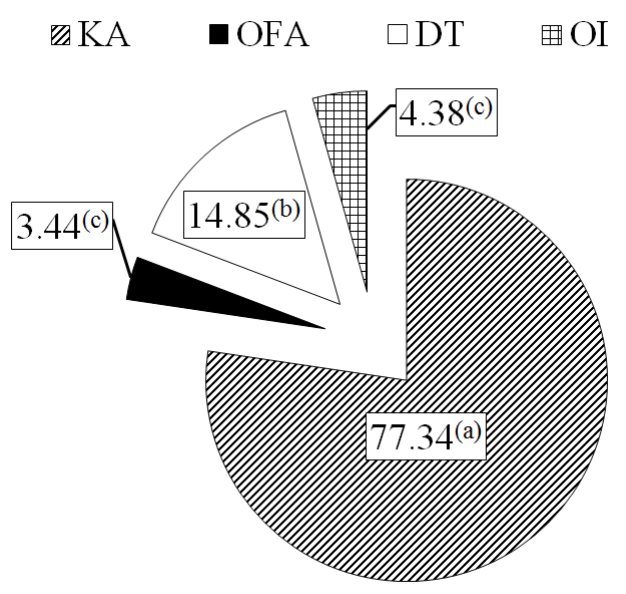

FIGURE 5. Average percentage of four food types in foreguts of 14 Hydropsyche larvae at the Kai-blooming site. Different letters (a), (b) and (c) indicate significant difference $(p<0.05) . \mathrm{KA}=$ Kai algae, OFA $=$ other filamentous algae, $\mathrm{DT}=$ diatoms, $\mathrm{OI}=$ other items.

\section{Comparison the food-type percentage between the Control and Kai-blooming sites}

Proportions of KA and OI at the Control site significantly differed from those at the Kai-blooming site (Table 1). Kai algae in the gut contents from the Kai-blooming site were proportionally higher than from the Control site. Similarly, proportions of diatoms and other items in the gut contents from the Control site were higher than at the Kai-blooming site because the Control site had more open area for diatom growth. However, Kai algae constituted the highest proportion of food items in both Potamyia and Hydropsyche foreguts at both sites, indicating that hydropsychid larvae purposefully consumed Kai algae during the Kai bloom period. Fairchild \& Holomuzki (2002) also reported that hydropsychid larval density was significantly greater in microhabitats of Cladophora than on biofilm-covered patches. In addition, algae help entrap other food for larvae. For example, Dudley et al. (1986) found that Hydropsyche spp. living in areas of macro-algae genera Cladophora and Nostoc consumed other organic components, such as leaves entrapped by the macro-algae. On the other hand, the studies of Benke \& Wallace (1980) and Wallace et al. (1987) found that although hydropsychid larvae were identified as omnivores, they consumed animal tissues and diatoms more than filamentous algae in subtropical blackwater streams.

TABLE 1. Percent comparisons of four food types in hydropsychid larval foreguts from the Control site and Kai-blooming site (The mean differences are significant at $\mathrm{p}<0.05$ ). $\mathrm{KA}=\mathrm{Kai}$ algae, $\mathrm{OFA}=$ other filamentous algae, $\mathrm{DT}=$ diatoms, $\mathrm{OI}=$ other items.

\begin{tabular}{lrcrr}
\hline & \multicolumn{4}{c}{$\begin{array}{c}\text { Average percentage of four food types } \\
(\mathbf{n = 1 4} \text { at each site) }\end{array}$} \\
\hline KA & \multicolumn{1}{c}{ OFA } & DT & OI \\
Control site & $41.26 \pm 14.06$ & $0.44 \pm 0.73$ & $21.90 \pm 5.20$ & $36.41 \pm 15.26$ \\
Kai-blooming site & $77.34 \pm 10.82$ & $3.44 \pm 6.07$ & $14.85 \pm 10.04$ & $4.38 \pm 5.21$ \\
Significance (p) & 0.000 & 0.111 & 0.081 & 0.000 \\
\hline
\end{tabular}

\section{Conclusions}

Hydropsychid larvae were identified as omnivores due to their consumption of filamentous algae, diatoms, insects, and vascular plants. During the Kai-blooming period, Kai algae genera Cladophora and Rhizoclonium 
in the Nan River are consumed by most hydropsychid larvae as the main food source, even in the areas with low abundance of algae. More studies about the feeding behavior and trophic relation of hydropsychid larvae in the Nan River during low Kai-algae-blooming periods may be required to confirm the selective feeding of the larvae on Kai algae.

\section{Acknowledgements}

Financial support by a Science Achievement Scholarship of Thailand (SAST) and the Biology Department of Chiang Mai University is acknowledged.

\section{References}

Benke, A.C. \& Wallace, J.B. (1980) Trophic basis of production among net-spinning caddisflies in a Southern Appalachian stream. Ecology, 61 (1), 108-118. https://doi.org/10.2307/1937161

Chaiyasuk, S. \& Waiyaka, P. (2001) The study of Kai (green algae) in ecosystems. The Thailand Research Fund (TRF), Chiang Mai, $80 \mathrm{pp}$.

Changthong, N. (2005) Spatial and temporal changes of Trichoptera community diversity and water quality from streams in Phu Hin Rong Kla National Park. Master of Science in Biology Thesis, Chiang Mai University, Chiang Mai, 96 pp.

Dudgeon, D. (1999) Tropical Asian streams: Zoobenthos, ecology and conservation. Hong Kong University Press, 830 pp.

Dudley, T.L., Cooper, S.D. \& Hemphill, N. (1986) Effects of macroalgae on a stream invertebrate community. Journal of the North American Benthological Society, 5 (2), 93-106. https://doi.org/10.2307/1467864

Fairchild, M.P. \& Holomuzki, J.R. (2002) Spatial variability and assemblage structure of stream hydropsychid caddisflies. Journal of the North American Benthological Society, 21, 576-588. https://doi.org/10.2307/1468431

Higgins, S.N., Malkin, S.Y., Howell, E.T., Guildford, S.J., Campbell, L., Hiriart-Baer, V. \& Hecky, R.E. (2008) An ecological review of Cladophora glomerata (Chlorophyta) in the Laurentian Great Lakes. Phycological Society of America, 44, 1-16. https://doi.org/10.1111/j.1529-8817.2008.00538.x

Hoang, D.C. \& Bae, Y.J. (2006) Aquatic insect diversity in a tropical Vietnamese stream in comparison with that in a temperate Korean stream. Limnology, 7, 45-55. https://doi.org/10.1007/s10201-006-0162-4

Kunpradid, T. (2005) Diversity of macroalgae and benthic diatoms and their relationships with nutrient compounds in the Ping and Nan Rivers. Doctor of Philosophy in Biology Dissertation. Chiang Mai University, Chiang Mai, $250 \mathrm{pp}$.

Kunpradid, T. \& Tagun, R. (2016) The influence of environmental factors on the distribution on macroalgae, Kai, Cladophora spp., Microspora spp. and Rhizoclonium spp. at Nan River, Tha Wang Pha District, Nan Province. Proceedings $4^{\text {th }}$ Rajabhat University National and International Research and Academic Conference (RUNIRAC IV). Buriram Rajabhat University, Buriram, pp. 419-427.

Laudee, P. \& Prommi, T. (2011) Biodiversity and distribution of Trichoptera species along the Tapee River, Surat Thani Province, southern Thailand. Zoosymposia, 5, 279-287.

https://doi.org/10.11646/zoosymposia.5.1.21

Lee, R.E. (2008) Phycology, 4th Edition, Cambridge University Press, New York, 547 pp.

Malicky, H. (1987) On some Rhyacophila from Doi Suthep Mountain, Northern Thailand. Trichoptera Newsletter, 14, $27-29$.

Malicky, H. (1999) The net-spinning larvae of the Giant Microcaddisfly, Ugandatrichia spp. (Trichoptera, Hydroptilidae). In: Malicky, H. \& Chantaramongkol, P. (Eds.), Proceedings of the 9th International Symposium on Trichoptera. Faculty of Science, Chiang Mai University, Chiang Mai, pp. 199-204.

Malicky, H. \& Chantaramongkol, P. (1993) The altitudinal distribution of Trichoptera species in Mae Klang Catchment on Doi Inthanon, Northern Thailand: Stream zonation and cool and warm-adapted groups. Revue d'Hydrobiologie Tropicale, 26 (4), 279-291.

Malicky, H. \& Chantaramongkol, P. (1999) A preliminary survey of the caddisflies (Trichoptera) of Thailand. In: Malicky, H. \& Chantaramongkol, P. (Eds.), Proceedings of the 9th International Symposium on Trichoptera. Faculty of Science, Chiang Mai University, Chiang Mai, pp. 205-216.

Moheimani, N.R.,Borowitzka, M.A., Isdepsky, A. \& Fon Sing, S. (2013) Standard methods for measuring growth of algae and their composition. In: Borowitzka, M.A. \& Moheimani, N.R. (Eds.), Algae for biofuels and energy: Developments in Applied Phycology. Springer Netherlands, Amsterdam, pp. 265-284.

https://doi.org/10.1007/978-94-007-5479-9_16

Oláh, J., Barnard, P.C. \& Malicky, H. (2006) A revision of lotic genus Potamyia Banks 1900 (Trichoptera: Hydropsychidae) 
with the description of eight new species. Linzer Biologische Beiträge, 38 (1), 739-777.

Peerapornpisal, Y. (2013) Freshwater Algae in Thailand. Faculty of Science, Chiang Mai University, Chiang Mai, 434 pp.

Peerapornpisal, Y., Pongsirikul, I. \& Kanjanapothi, D. (2005) Potential Use of Freshwater Macroalgae as Food and Drugs. Thailand Research Fund (TRF), Chiang Mai, 183 pp.

Prommi, T. \& Thamsenanupap, P. (2015) Diversity and structure of Trichoptera communities and water quality variables in streams, northern Thailand. World Academy of Science, Engineering and Technology International Journal of Environmental and Ecological Engineering, 9 (9), 1065-1072.

Pruetiworanan, S. (2008) Diversity of Macroalgae and Benthic Diatoms in Mekong River Passing Thailand and Their Application for Water Quality Monitoring. Master of Science in Biology Thesis. Chiang Mai University. Chiang Mai, 154 pp.

Rawi, C.S.M., Al-Shami, S.A., Madrus, M.R. \& Ahmad, A.H. (2013) Biological and ecological diversity of aquatic macroinvertebrates in response to hydrological and physicochemical parameters in tropical forest streams of Gunung Tebu, Malaysia: Implications for ecohydrological assessment. Ecohydrology 2013, 7, 496-507. https://doi.org/10.1002/eco.1368

Silalom, S. (2008) Development of a Rapid Biological Assessment Protocol for Water Quality in the Upper Sub-Watershed of the Ping River as Applied to Tropical Lotic Ecosystems. Doctor of Philosophy in Biology Dissertation, Chiang Mai University, Chiang Mai, 144 pp.

Takeaw, S. (2014) The Use of Macroinvertebrates as Water Quality Bioindicators in Mae Chaem District, Chiang Mai Province. Master of Science in Biology Thesis, Chiang Mai University, Chiang Mai, 85 pp.

Thawaroroit, K. \& Sangpradub, N. (2016) Diversity and distribution of larval caddisflies in the protected areas; Phu Kradueng National Park, Loei Province and Phu Khieo Wildlife Sanctuary, Chaiyaphum Province. Princess of Naradhiwas University Journal, 8 (1), 101-110.

Thongdej, N. (2012) Diversity of Macroinvertebrate Assemblages from Spring Sources and Foothill Stream of Doi Suthep, Chiang Mai. Bachelor of Science in Biology Special Project, Chiang Mai University, Chiang Mai, 65 pp.

Traichaiyaporn, S. (2012) Kai Algae: Natural Heritage and Sustainable Culture. Department of Biology, Faculty of Science, Chiang Mai University, Chiang Mai, 72 pp.

Van den Hoek, C. (1963) Revision of the European species of Cladophora. The Netherlands Organization for the Advancement of Pure Research, Leiden, 248 pp.

Wallace, J.B., Benke, A.C. \& Lingle, A.H. (1987) Trophic pathways of macroinvertebrate primary consumers in subtropical blackwater streams. Archiv für Hydrobiologie Supplement, 74, 423-451.

Wangpimool, W., Pongput, K., Sukvibool, C., Sombatpanit, S. \& Gassman, P.W. (2013) The effect of reforestation on stream flow in Upper Nan River Basin using Soil and Water Assessment Tool (SWAT) Model. International Soil and Water Conservation Research, 1 (2), 53-63. https://doi.org/10.1016/S2095-6339(15)30039-3

Whitton, B.A. (1970) Review paper biology of Cladophora in freshwaters. Water Research Pergamon Press, 4, 457-476. https://doi.org/10.1016/0043-1354(70)90061-8 